\title{
A comparative study of the adsorption of azo dyes in mixed adsorbents composed of Aspergillus niger and Citrus sinensis chemically modified: Influence of pH
}

\section{Liliane Martins Marques ${ }^{1}$, Andressa Nathally Rocha Leal ${ }^{2}$, Alice da Conceição Alves de Lima², Dayane Kelly Dias do Nascimento Santos ${ }^{3}$, Karina Carvalho de Souza $^{4}$ and Iranildo José da Cruz-Filho ${ }^{5}$}

\footnotetext{
${ }^{1}$ Universidade Federal de Pernambuco. Curso de Graduação em Ciências Biológicas com ênfase em Ciências Ambientais. Campus Recife. Av. Professor Moraes Rego, 1235. Cidade Universitária. Recife-PE, Brasil (CEP 50670-901).

2Universidade Federal de Pernambuco. Curso de Graduação em Engenheira Química. Campus Recife. Av. Professor Moraes Rego, 1235. Cidade Universitária. Recife-PE, Brasil (CEP 50670-901).

${ }^{3}$ Universidade Federal de Pernambuco. Curso de Graduação em Biomedicina. Campus Recife. Av. Professor Moraes Rego, 1235. Cidade Universitária. Recife-PE, Brasil (CEP 50670-901).

${ }^{4}$ Universidade Federal de Pernambuco. Curso de Graduação em Química Industrial. Campus Recife. Av. Professor Moraes Rego, 1235. Cidade Universitária. Recife-PE, Brasil (CEP 50670-901).

${ }^{5}$ Universidade Federal de Pernambuco. Curso de Graduação em Química. Campus Recife. Av. Professor Moraes Rego, 1235. Cidade Universitária. Recife-PE, Brasil. (CEP 50670-901). E-mail: iranildoj@gmail.com.
}

\begin{abstract}
The economic growth of the textile sector in Brazil has contributed to the generation of new jobs, qualification of the workforce and better living conditions for the population. However, due to the high activity of the sector, large volumes of toxic effluents have been generated which, if improperly disposed of, cause serious environmental damage. Therefore, alternatives in the treatment of effluents are interesting to increase the availability of this resource. A technique that has stood out, for being efficient, easy to operate and economical, is adsorption, a passive capture process where pollutants are deposited on the surface of materials. Thus, the work aimed to carry out a comparative study of the influence of $\mathrm{pH}$ in the removal of the dyes Remazol Black (RB), Remazol Red (RR) and Remazol Yellow (RGY) using different mixed adsorbents constituted by the fungus Aspergillus niger grown in orange peel in two different culture media. Six types of adsorbents (three for each culture medium) were produced and were treated with acid, base and without treatment. These were subjected to adsorption tests at different
\end{abstract}

Received

October 30, 2020

Accept

March 30, 2021

Available online April 04, 2021

Released

April 30, 2021

Open access

ISSN 2359-1412/RBGAS-2020-0160/2021/8/18/7/121

Rev. Bras. Gest. Amb. Sustent.

http://revista.ecogestaobrasil.net 
pHs (2, 7 and 9), using a solution $\left(25 \mathrm{mg} \cdot \mathrm{L}^{-1}\right)$ volume of $100 \mathrm{~mL}$, $0.5 \mathrm{~g}$ of biomass, rotation $150 \mathrm{rpm}, 30^{\circ} \mathrm{C}$. The results showed that the adsorbents produced were able to adsorb the dyes RB, RGY, $\mathrm{RR}$ at different pHs. The best adsorption condition was obtained at $\mathrm{pH} 2$ and the adsorbents were treated with acid, showing a promising alternative for the treatment of textile effluents.

Keywords: Effluent treatment; Water quality; Textile dyes.

Resumo. Estudo comparativo da adsorção de corantes azo em adsorventes mistos compostos por Aspergillus niger $e$ Citrus sinensis quimicamente modificados: influência do $\mathrm{pH}$. $\mathrm{O}$ crescimento econômico do setor têxtil no Brasil tem contribuído para a geração de novos empregos, qualificação da mão de obra e melhores condições de vida para a população. Entretanto, devido à alta atividade do setor, tem se gerado grandes volumes de efluentes tóxicos que se descartados de forma inadequada causam sérios danos ambientais. Sendo assim, alternativas no tratamento de efluentes são interessantes para aumentar a disponibilidade deste recurso. Uma técnica que vem se destacando, por ser eficiente, de fácil operação e econômica é a adsorção, um processo de captação passiva onde os poluentes depositam-se na superfície de materiais. Assim, o trabalho teve como objeto realizar um estudo comparativo da influência do $\mathrm{pH}$ na remoção dos corantes Remazol Black (RB), Remazol Red (RR) e Remazol Yellow (RGY) utilizando diferentes adsorventes mistos constituídos pelo fungo Aspergillus niger crescido em casca de laranja em dois diferentes meios de cultura. Foram produzidos seis tipos de adsorventes (três para cada meio de cultura) e foram submetidos a tratamento com ácido, base e sem tratamento. Estes foram submetidos a ensaios de adsorção em diferentes pHs $(2,7$ e 9), utilizaram-se um volume de solução $\left(25 \mathrm{mg} \cdot \mathrm{L}^{-1}\right)$ de $100 \mathrm{~mL}$, $0,5 \mathrm{~g}$ de biomassa, agitação $150 \mathrm{rpm}, 30^{\circ} \mathrm{C}$. Os resultados mostraram que os adsorventes produzidos foram capazes de adsorver os corantes RB, RGY, RR em diferentes pHs. A melhor condição de adsorção foi obtida em pH 2 e os adsorventes tratados com ácido. Sendo assim estes adsorventes tem se mostrando uma alternativa promissora para o tratamento de efluentes têxteis.

Palavras-chave: Tratamento de efluentes; Qualidade da água; Corantes têxteis.

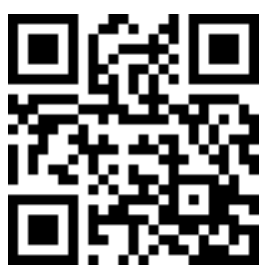

ORCID

(D) 0000-0003-1777-606X

Liliane Martins

Marques

(ㄷ) 0000-0001-9920-1096

Andressa Nathally

Rocha Leal

(D) 0000-0001-6656-3066

Alice da Conceição

Alves de Lima

(D) 0000-0002-5650-1088

Dayane Kelly Dias do

Nascimento Santos

(D) 0000-0002-9902-7566

Karina Carvalho de

Souza

(1) 0000-0002-5466-6567

Iranildo José da

Cruz-Filho

\section{Introduction}

The textile sector is one of the most complex and traditional sectors on the planet (Panigrahi et al., 2020). Its production chain begins with the production of fibers and filaments, including spinning, weaving, knitting, finishing and making (Basak et al., 2020). Its industries, or at least part of them, are distributed all over the world, from countries 
with less economic development, as well as more developed ones (Basak et al., 2020; Srivastava et al., 2020; Silva et al., 2021).

Brazil is one of the largest textile producers in the world (ABIT, 2020). In 2019, an average of 8.9 billion pieces were produced in the country (clothing, accessories, bed, table and bath), the sector generated an average of 1.5 million direct employees and 8 million indirectly and had revenues of US\$ 48.3 billion (ABIT, 2020). The textile hubs of the Brazil that deserve to be highlighted are Ceará, Agreste Pernambucano, Vale do Itajaí, in the State of Santa Catarina, and the Americana hub, in São Paulo (FEBRATEX, 2020a).

The center located in Agreste Pernambucano, formed mainly by the cities of Santa Cruz do Capibaribe, Toritama and Caruaru, is the second largest producer of clothing in the country, according to the National Service for Industrial Learning (SENAI), second only to São Paulo (FEBRATEX, 2020b; Esteves, 2020). The region receives customers from all over the country, predominantly from the North and Northeast States (Esteves, 2020). In recent years, the demand for buyers from the Midwest and, even more, the Southeast has grown, like Minas Gerais and Espírito Santo (Esteves, 2020; FEBRATEX, 2020b). The high shopping season occurs in June and July, and from November to December (Esteves, 2020).

The beauty of the textile sector is in the pieces produced, these have strong and vibrant colors which draw the attention of the consuming public (Srivastava et al., 2020). Among the different dyes used in dyeing are the azo dyes $(-\mathrm{N}=\mathrm{N}-)$, they are widely used by the textile industries because they are easy to produce, low cost and present a wide variety of colors, in addition to being soluble in water (Nazir et al., 2020). However, during the dyeing process large volumes of water are used, resulting in a colored effluent that, when improperly disposed of, causes serious problems to both human health and the aquatic ecosystem (Song et al., 2020).

The treatment of effluents containing azo dyes has become a worldwide challenge, since many physical and chemical methods do not completely remove this type of dye, besides being operationally expensive methods, and with the generation of quite toxic byproducts (Panigrahi et al., 2020). So, adsorption has become an effective alternative for the removal of these pollutants in water, since it is a simple technique, easy to operate and low cost (Nazir et al., 2020). Different adsorbent materials have been studied, however, the ones that have gained prominence due to the abundance and also the low cost are the natural adsorbents (Khalaf, 2008; Saratale et al., 2013; Huang et al., 2016). Different adsorbent materials can be used to remove dyes, macadamia seed peels (Felista et al., 2020), chitosan (Ammadurai et al., 2007), Aspergillus niger/elephant grass (Cruz-Filho et al., 2016), and activated carbon derived from coconut shell (Furlan et al., 2010).

Therefore, this study aimed to evaluate the influence of $\mathrm{pH}$ in the removal of the dyes Remazol Black, Remazol Red and Remazol Yellow, using as mixed adsorbent the mixed biomass composed by the fungus Aspergillus niger grown in orange peel, in order to obtain higher percentages removal and decrease costs with the treatment of textile effluents.

\section{Materials e methods}

\section{Adsorbate}

The dyes used in this work were: Remazol Black B (RB) (Figure 1A), Remazol Golden Yellow RNL (RGY) (Figure 1B) and Remazol Red (RR) (Figure 1C) at maximum wavelengths 597, 410 and $518 \mathrm{~nm}$, respectively (Aksu et al., 2005). 

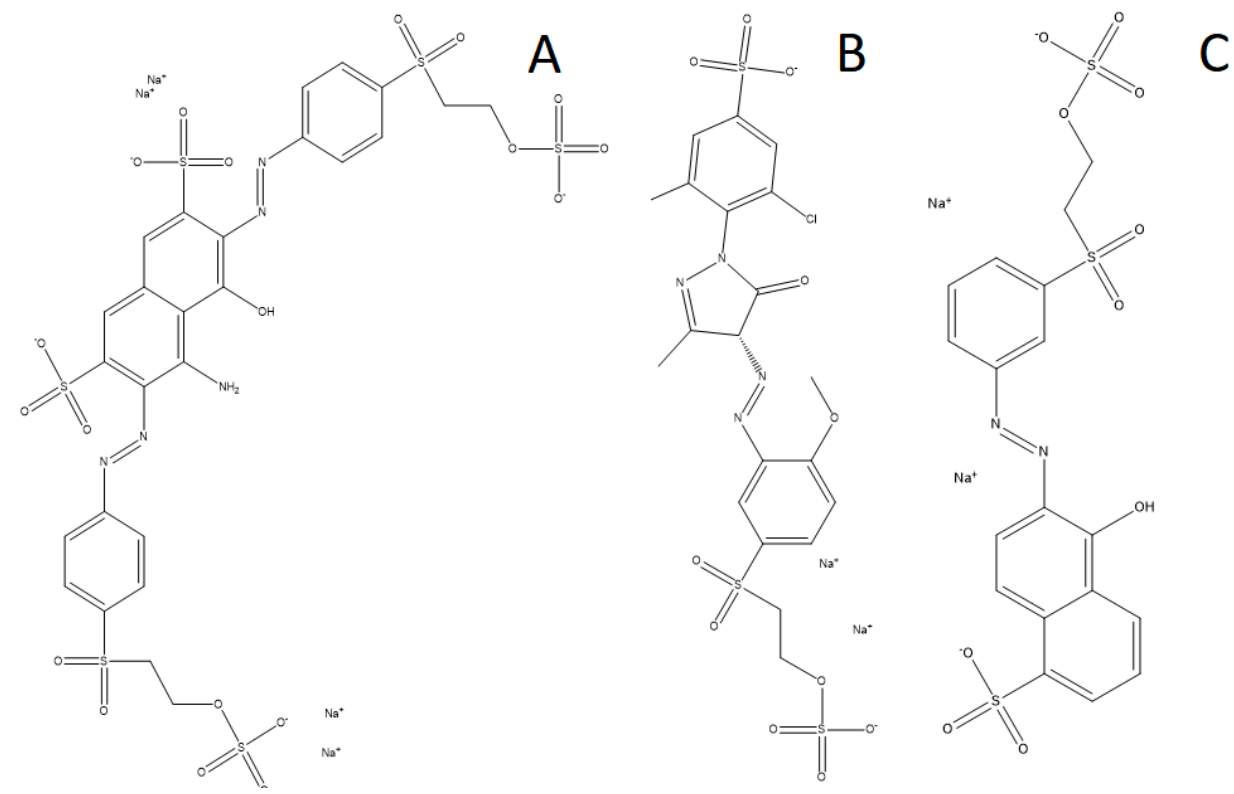

Figure 1. Chemical structure of textile dyes. Remazol Black B (A), Remazol Golden Yellow RNL (B) and Remazol Red (C)

For the construction of the analytical curves, $100 \mathrm{~mL}$ of stock solutions of the dyes were prepared in a concentration of $200 \mathrm{mg} \cdot \mathrm{L}^{-1}$. From this concentration, different dilutions were performed to reach concentrations from 0 to $105 \mathrm{mg} \mathrm{L}^{-1}$ and, in this way, build the calibration curve. After being prepared, an aliquot was removed from each solution for later absorbance reading, in a spectrophotometer (Hewlett-Packard, model 8453), at the respective wavelengths. Distilled water was used as the white of the equipment. The data obtained were used to construct the graphs of the calibration curves.

\section{Study of the stability of dye solutions at different $\mathrm{pH}$}

The evaluation of the degradation of the dye (in relation to time) was carried out according to Zanon (2006) with modifications. This study was carried out using different solutions of the dyes (RB, RGY and RR) in a concentration of $25 \mathrm{mg} \cdot \mathrm{L}^{-1}$. For this experiment, $100 \mathrm{~mL}$ of dye solution were added to a $250 \mathrm{~mL}$ Erlenmeyer flask at $30{ }^{\circ} \mathrm{C}$ with agitation of $150 \mathrm{rpm}$ at different pHs (2, 7 and 9). Every $20 \mathrm{~min}$ for $240 \mathrm{~min}, 3.0 \mathrm{~mL}$ aliquots were analyzed on a spectrophotometer.

\section{Production of mixed adsorbent}

The orange peels used in this work were obtained from snack bars located at $8^{\circ} 02^{\prime} 37.5^{\prime \prime}$ S and $34^{\circ} 56^{\prime}$ 57.3' W, Recife, Pernambuco State, Brazil. They were crushed in a blender, then they were cut, washed with distilled water and dried at $75{ }^{\circ} \mathrm{C}$ for $72 \mathrm{~h}$. After drying, they were crushed and sieved again in Tyler sieves $(1.43 \mathrm{~mm})$. The microorganism used was the filamentous fungus Aspergillus niger (ATCC 1015) from the collection of microorganisms from the Industrial Microbiology Laboratory, of the Department of Chemical Engineering (DEQ), of the Federal University of Pernambuco (UFPE). The fungal mass was grown in Czapec-Dox medium for approximately 7 days in an oven at a temperature of $30^{\circ} \mathrm{C}$. 
The methodology proposed by Cruz et al. (2016) was used to prepare the mixed adsorbent with few modifications. A volume of $5 \mathrm{~mL}$ of spore suspension $\left(10^{7}\right.$ spores $\left.\mathrm{mL}^{-1}\right)$ was inoculated in $250 \mathrm{~mL}$ in two different culture mediums, one with sucrose (MCS) consisting of $\mathrm{NaNO}_{3}(3.0 \mathrm{~g}), \mathrm{KH}_{2} \mathrm{PO}_{4}(1,0 \mathrm{~g}), \mathrm{MgSO}_{4} .7 \mathrm{H}_{2} \mathrm{O}(0.5 \mathrm{~g}), \mathrm{FeSO}_{4}(0.01 \mathrm{~g}$ ), sucrose ( $3.3 \mathrm{~g}$ ) and orange peels (6.7 g). The second without sucrose (MSS) composed of $\mathrm{NaNO}_{3}$ (3.0 g), $\mathrm{KH}_{2} \mathrm{PO}_{4}(1.0 \mathrm{~g}), \mathrm{MgSO}_{4} .7 \mathrm{H}_{2} \mathrm{O}(0.5 \mathrm{~g}), \mathrm{FeSO}_{4}(0.01 \mathrm{~g})$ and orange peels $(10 \mathrm{~g})$. All experiments were carried out under aseptic conditions. After inoculation, the tests were kept under agitation at $200 \mathrm{rpm}$ at $30^{\circ} \mathrm{C}$ for $72 \mathrm{~h}$. At the end of the cultivation, the material produced was autoclaved at $121^{\circ} \mathrm{C}$ for $30 \mathrm{~min}$, filtered and then washed with sterile water and dried in an oven at $75^{\circ} \mathrm{C}$.

The material produced by each of the MCS and MSS culture medium was divided into three aliquots and classified according to the chemical treatment submitted, thus having: i) samples without treatment; ii) treated with hydrochloric acid ( $\mathrm{HCl}) 1.0 \mathrm{~mol} \cdot \mathrm{L}^{-1}$ for $1 \mathrm{~h}$ and iii) treated with sodium hydroxide $(\mathrm{NaOH}) 1.0 \mathrm{~mol} \cdot \mathrm{L}^{-1}$ also for $1 \mathrm{~h}$ (Chaves et al., 2008; Cruz et al., 2016). After treatment, the samples were washed with plenty of distilled water to remove the treatment solution and taken to the oven at $75^{\circ} \mathrm{C}$ for drying. Thus, six different adsorbents were produced: A1 (without treatment), A2 (acid) and A3 (basic) from the MCS medium and B1 (without treatment), B2 (acid) and B3 (basic) from the MSS medium.

\section{Influence of $\mathrm{pH}$ in the removal process}

To evaluate the influence of $\mathrm{pH}$ in the adsorption process, a methodology proposed by Cruz et al. (2016), Nascimento et al. (2017) and Molavi et al. (2018). For this, solutions of the dyes (RB, RGY and RR) were prepared at $\mathrm{pH}=2$ (acidic), $\mathrm{pH}=7$ (neutral) and $\mathrm{pH}=9$ (basic). The $\mathrm{pH}$ values were adjusted using solutions of sulfuric acid and $3 \mathrm{M}$ sodium hydroxide. The adsorption experiments were carried out in batches in Erlenmeyers flasks, containing $100 \mathrm{~mL}$ of the solution ( $25 \mathrm{mg} \cdot \mathrm{L}^{-1}$ ) of each dye, $0.5 \mathrm{~g}$ of each mixed adsorbent, with fixed temperature and agitation of $30{ }^{\circ} \mathrm{C}$ and $150 \mathrm{rpm}$, respectively, for a period of $12 \mathrm{~h}$. At the end of this test, an aliquot of the supernatant was removed and the final concentration of the dye present in the solution was analyzed in a UV-VIS spectrophotometer (Hewlett-Packard, model 8453) at their respective wavelengths. The tests were performed in triplicate and the percentage of dye removal ( $\% \mathrm{R})$ was determined by Equation 1.

$$
R(\%)=\left(\frac{C_{0}-C_{f}}{C_{0}}\right) * 100
$$

Where $\mathrm{C}_{0}$ and $\mathrm{C}_{\mathrm{f}}$ are the initial and final concentrations of the dye in the liquid phase $(\mathrm{mg} / \mathrm{L})$ respectively.

\section{Results and discussion}

The calibration curves of the UV-VIS spectrophotometer for the dyes RB, RGY and RR at the wavelengths of 597, 410 and $518 \mathrm{~nm}$ are shown in Figure 2A, respectively. The results showed good linearity for the dyes under study. The results obtained, as shown in Figure 2B, 2C and 2D, demonstrate a small variation in the recorded absorbance, with no 
significant change in the dye structure. This is because the azo compounds are found in the form of hydrazo tautomer, its most stable form (Zanon, 2006; Nazir et al., 2020).
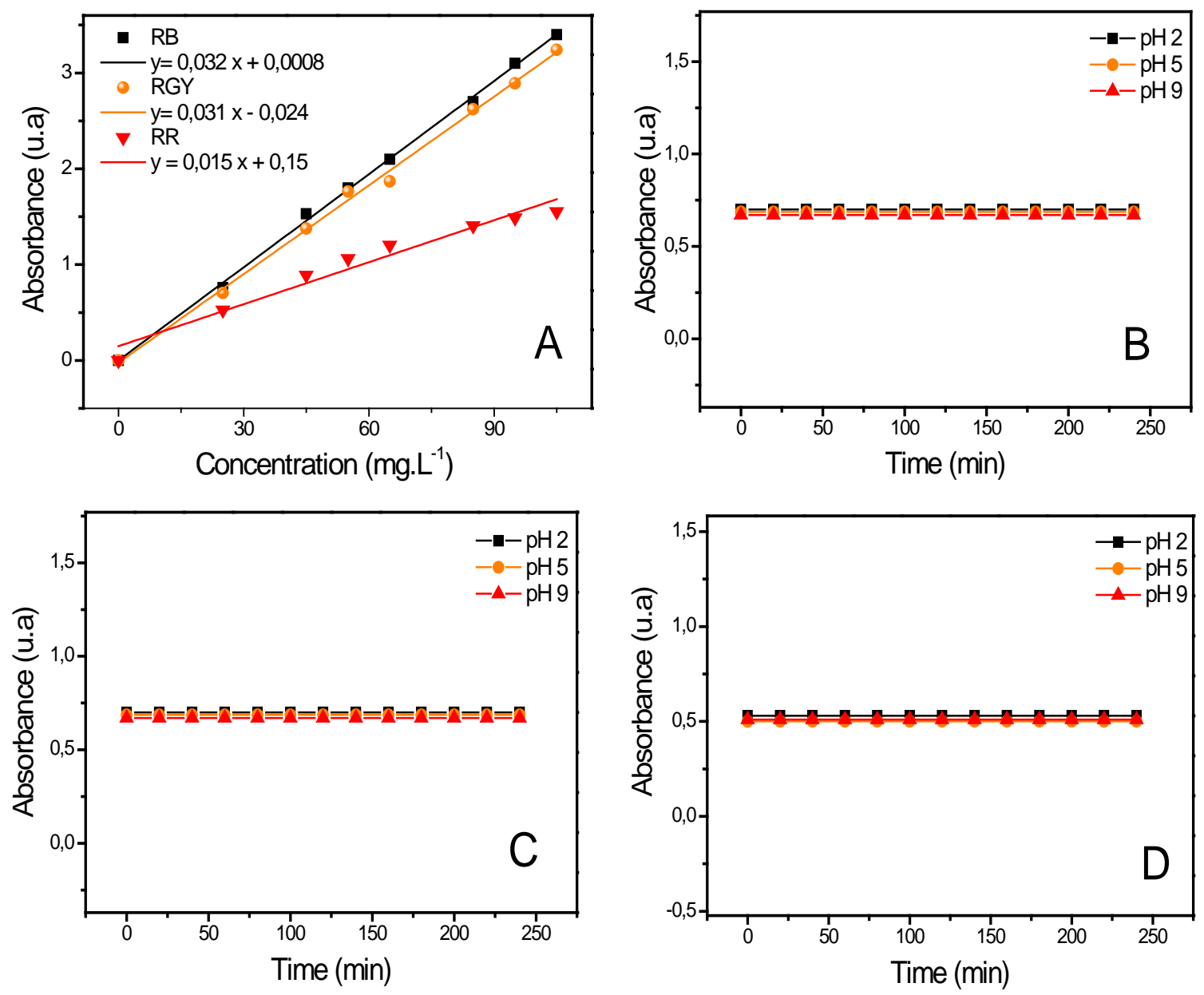

Figure 2. Calibration curve for the dye RB, RGY and RR (A), stability curves for the dye RB (B), (C) and (D).

The $\mathrm{pH}$ has a great influence on the dye adsorption process. Thus, a study was carried out to identify the best $\mathrm{pH}$ for carrying out the adsorption (Mahmoodi et al., 2011). The Figure 3 shows the percentage of removal of the adsorbents against the dyes RB, RGY and $\mathrm{RR}$ in relation to $\mathrm{pH}$.

The results showed that all adsorbents produced showed higher percentages of removal at $\mathrm{pH}$ 2. For the $\mathrm{RB}$ dye (Figures $3 \mathrm{~A}$ and $3 \mathrm{~B}$ ) the acid-treated adsorbent showed higher percentages of removal at all studied pHs. For Remazol Golden Yellow RNL (Figure $3 \mathrm{C}$ and 3D) the adsorbents showed a percentage of removal $<50 \%$, and the base-treated adsorbent removed even with less efficiency at all pHs. For Remazol Red (Figures 3E and 3F) the base-treated adsorbents also promoted adsorption in a greater $\mathrm{pH}$ range. Therefore, the best process condition for this study was $\mathrm{pH} 2$ and acid-treated adsorbents. In this case, as the adsorbents produced in medium containing or not sucrose showed a 
significant difference in the adsorption process. Regarding the production cost of the adsorbent, the adsorbent produced in a medium without sucrose was chosen.
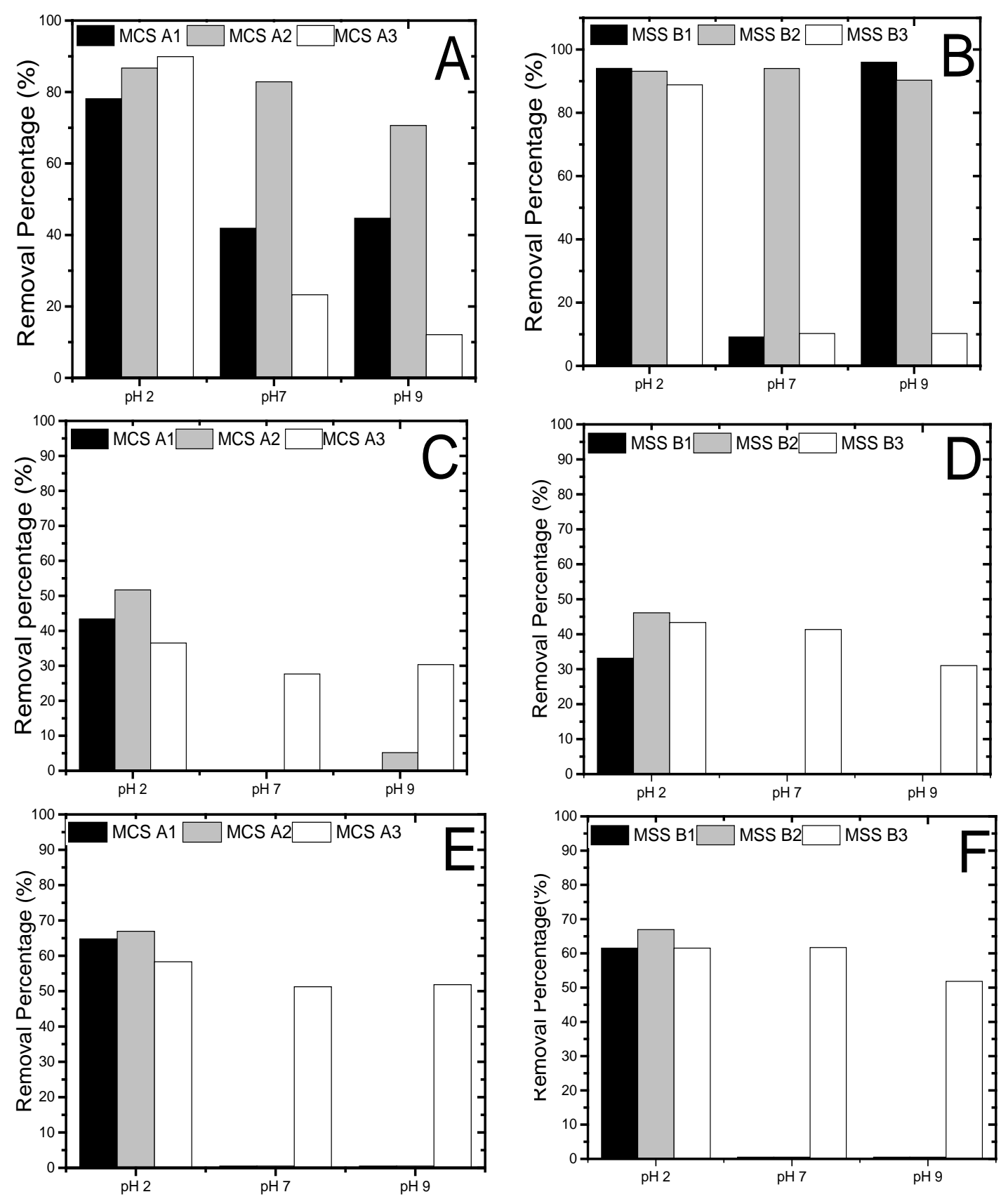

Figure 3. Comparison of the percentage of removal of adsorbents A1 (without treatment), A2 (acid) and A3 (basic) from the MCS medium. For SSS medium, adsorbents B1 (without treatment), B2 (acid) and B3 (basic) at different pH values: for Remazol Black B (A, B) Remazol Golden Yellow RNL (C, D) Remazol Red (E, F)

The adsorption mechanism between $\mathrm{pH} 1-4$ is mainly due to electrostatic interactions. For this $\mathrm{pH}$ range, some of the groups of the adsorbent surface will be 
protonated and the adsorbent-dye interaction may occur via sulfonic groups of the dye (Mahmoodi et al., 2011). The Figure 4 represents the simplified electrostatic mechanism for this three-step interaction. In the first one, it can be seen that the hydroxyl groups of the adsorbent are protonated by the hydronic ions and dye molecules are dissociated by water, resulting in the interaction between opposite charges of the adsorbent and with the dye.

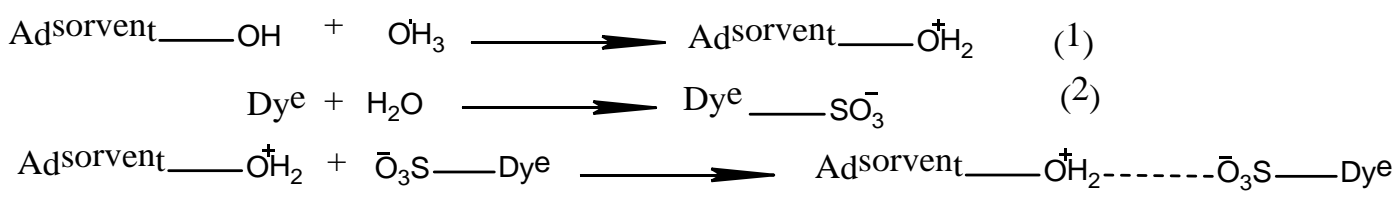

Figure 4. Adsorption mechanism simplified in three stages showing the interaction via dye adsorption charges.

Other authors have also found similar behavior for the removal of RB, RGY and RR dyes. In studies with the RB dye. Cruz-Filho et al. (2016) also using mixed adsorbent composed of elephant grass and Aspergillus niger obtained removal around $96 \%$ in acidic conditions $\mathrm{pH}$ 2. Tunç et al. (2009) removing the same dye using cotton waste, stem and bark verified greater removals at $\mathrm{pH}$ 1.0. Ziapour et al. (2016) using sugarcane bagasse they verified that at pH 2.5 there is a removal around 55\%. Hamzeh et al. (2011) using lignocellulosic residue from canola stems obtained removal around $80 \%$ at $\mathrm{pH} 2.5$. Ucar, (2014), using pine needles obtained 91.51\% removal at pH 3.0. Sukarta, (2020) obtained greater removal in $\mathrm{pH} 2$ using cream of pin as adsorbent.

Regarding the RGY dye, satisfactory removals at acid pH were also obtained. Nascimento et al. (2014) using peanut peel and orange peel found greater removals at $\mathrm{pH}$ 2 , with peanut peels being more efficient at removal. This same behavior was found by Nascimento et al. (2016), using banana peel and green coconut mesocarp the authors found that the green coconut mesocarp was more efficient in removal when compared to banana peels. Nugroho et al. (2008) evaluating a mixed adsorbent fungal biomass and activated carbon found better removal results at $\mathrm{pH} 1(<95 \%)$ when compared to activated carbon at the same $\mathrm{pH}$ removal around 65\%. This difference may be associated with the groups present in the fungal biomass.

In adsorption tests with RR dye, promising adsorbents were also found in the removal of the dye. Costa et al. (2019) obtained 90\% removal at $\mathrm{pH} 2$ using rice husk ash as an adsorbent. Chaudhuri et al. (2011), coconut activated carbon was used as an adsorbent removed around $80 \%$ of the dye over a wide $\mathrm{pH}$ range (1-10). Dey et al. (2016) found higher removal values at $\mathrm{pH} 3$ with chitosan as an adsorbent. Ara et al. (2013) obtained 95\% removal percentage at $\mathrm{pH} 2$ using sawdust.

In addition to the adsorption study for the dyes under study in isolation, the literature presents comparative studies. Aksu et al. (2005) using seaweed Chlorella vulgaris as an adsorbent, he verified that the algae biomass removed the RB dye more efficiently, then the RR and RGY dyes. Thus, the differences in the removal of dyes by the adsorption process are directly related to the conditions of the process and the $\mathrm{pH}$ is only one parameter. The type of adsorbent, the quantity, the temperature, agitation, structural complexity of the dyes must be taken into account in order to obtain the best process condition (Arulkumar et al. 2011; Cruz-Filho et al., 2016). 


\section{Conclusion}

Through this study, it can be concluded that through chemical modifications of the adsorbent surface it is possible to obtain biomaterials with different adsorptive capacity. The adsorbent Aspergillus niger/orange peel produced in different medium was able to adsorb different azo dyes (RB, RGY, RR) at different pHs. The best process condition was obtained at pH 2 and acid-treated adsorbents. In addition, the mixed adsorbent culture medium (with or without sucrose) did not influence the ability to capture the dyes through the substrate. Thus, the adsorbents produced are promising alternatives for efficient materials for the treatment of textile effluents.

\section{Conflicts of interest}

The authors declare that have no conflicts of interest.

\section{References}

ABIT - Associação Brasileira da Indústria Têxtil e de Confecção. 2019. Available from: <https://www.abit.org.br/cont/perfil-do-setor>. Accessed on: Oct. 24, 2020.

Aksu, Z.; Tezer, S. Biosorption of reactive dyes on the green alga Chlorella vulgaris. Process Biochemistry, v. 40, p. 1347-1361, 2005. https://doi.org/10.1016/j.procbio.2004.06.007

Ammadurai, G.; Ling, L. Y.; Lee, J.-F. Adsorption of reactive dye from an aqueous solution by chitosan: Isotherm, kinetic and thermodynamic analysis. Journal of Hazardous Materials, v. 152, p. 337-346, 2007. https://doi.org/10.1016/j.jhazmat.2007.07.002

Ara, N. J.; Hasan, M. A.; Rahman, M. A.; Salam, M. A.; Salam, A.; Alam, A. S. Removal of remazol red from textile waste water using treated sawdust-an effective way of effluent treatment. Bangladesh Pharmaceutical Journal, $\quad$ v. 16, p. 93-98, 2013. https://doi.org/10.3329/bpj.v16i1.14501

Arulkumar, M.; Sathishkumar, P.; Palvannan, T. Optimization of Orange G dye adsorption by activated carbon of Thespesia populnea pods using response surface methodology. $\begin{array}{lllll}\text { Journal of Hazardous } & \text { Materials, } & \text { v. 186, }\end{array}$ https://doi.org/10.1016/j.jhazmat.2010.11.067

Basak, S.; Senthilkumar, T.; Krishnaprasad, G.; Jagajanantha, P. Sustainable development in textile processing. In: Inamuddin; Asiri, A. M. (Eds.). Sustainable green chemical processes and their allied applications. Cham: Springer, 2020. p. 559-573. https://doi.org/10.1007/978-3-030-42284-4_20

Chaudhuri, M.; Elmolla, E. S.; Othman, R. Bt. adsorption of reactive dyes Remazol Red F-3B and Remazol Blue from aqueous solution by coconut coir activated carbon. Nature Environment and Pollution Technology, v. 10, no. 2, p. 193-196, 2011.

Chaves, K. O.; Monteiro, C. R. L.; Muniz, C. R.; Gomes, R. B.; Buarque, H. L. D. B. Adsorção de índigo carmim em biomassas mortas de Aspergillus niger. Engenharia Sanitária e Ambiental, $\quad$ v. 13 , no. 4 , p. 351-5355, 2008. https://doi.org/10.1590/S141341522008000400001

Costa, J. A. S.; Paranhos, C. M. Evaluation of rice husk ash in adsorption of Remazol Red dye from aqueous media. SN Applied Sciences, v. 1, Article Number 397, 2019. https://doi.org/10.1007/s42452-019-0436-1 
Cruz, I. J.; Marques, L. M.; Souza, K. C.; Lima, V. F.; Marques, O. M.; Nascimento Junior, A. J. Remoção do corante Remazol Black B pelo uso da biomassa mista de Aspergillus niger e capim elefante (Pennisetum purpureum Schum). Engevista, v. 18, p. 265-279, 2016. https://doi.org/10.22409/engevista.v18i2.727

Cruz-Filho, I. J.; Ferreira, H. K. L.; Silva, S. K. G.; Machado, S. E. F.; Zaidan, L. E. M. C.; Lima, V. F.; Marques, O. M.; Nascimento-Junior, A. J. Otimização do processo de remoção do corante Preto de Remazol B por uso de biomassa mista de Aspergillus niger van Tieghem, 1867 (Ascomycota: Trichocomaceae) e Pennisetum purpureum Schumach., 1827 (Poales: Poaceae). Revista Brasileira de Gestão Ambiental e Sustentabilidade, v. 3, no. 6, p. 375-384, 2016. https://doi.org/10.21438/rbgas.030611

Dey, S. C.; Al-Amin, M.; Rashid, T. U.; Sultan, M. Z.; Ashaduzzaman, M.; Sarker, M.; Shamsuddin, S. M. Preparation, characterization and performance evaluation of chitosan as an adsorbent for remazol red. International Journal of Latest Research in Engineering and Technology, v. 2, p. 52-62, 2016.

Esteves, E. Polo de confecções do Agreste, um potencial ainda pouco conhecido. LeiaJa, 2020. Available from: <http://especiais.leiaja.com/descosturandoacrise/materia1.html>. Accessed on: Oct. 24, 2020.

FEBRATEX - Feira Brasileira para a Indústria Têxtil. 2019a. Available from: $<$ https://fcem.com.br/noticias/quais-sao-os-principais-polos-da-industria-textil-dobrasil/>. Accessed on: Oct. 24, 2020.

FEBRATEX - Feira Brasileira para a Indústria Têxtil. 2019b. Available from: $<$ https://fcem.com.br/noticias/entenda-a-influencia-do-polo-textil-no-agrestepernambucano $>$. Accessed on: Oct. 24, 2020.

Felista, M. M.; Wanyonyi, W. C.; Ongera, G. Adsorption of anionic dye (Reactive Black 5) using macadamia seed Husks: Kinetics and equilibrium studies. Scientific African, v. 7, e00283, 2020. https://doi.org/10.1016/j.sciaf.2020.e00283

Furlan, F. R.; Silva, L. G. M.; Morgado, A. F.; Souza, A. A. U.; Souza, S. M. A. G. U. Removal of reactive dyes from aqueous solutions using combined coagulation/flocculation and adsorption on activated carbon. Resources, Conservation and Recycling, v. 54, p. 283-290, 2010. https://doi.org/10.1016/j.resconrec.2009.09.001

Hamzeh, Y.; Azadeh, E.; Izadyar, S.; Karaj, I. Removal of reactive Remazol Black B from contaminated water by lignocellulosic waste of canola stalks. Journal of Color Science and Technology, v. 5, p. 77-85, 2011.

Huang, J.; Liu, D.; Lu, J.; Wang, H.; Wei, X.; Liu, J. Biosorption of Reactive Black 5 by modified Aspergillus versicolor biomass: Kinetics, capacity and mechanism studies. Colloids and Surfaces A: Physicochemical and Engineering Aspects, v. 492, p. 242-248, 2016. https://doi.org/10.1016/j.colsurfa.2015.11.071

Khalaf, M. A. Biosorption of reactive dye from textile wastewater by non-viable biomass of Aspergillus niger and Spirogyra sp. Bioresource Technology, v. 99, p. 6631-6634, 2008. https://doi.org/10.1016/j.biortech.2007.12.010

Mahmoodi, N. M.; Hayati, B.; Arami, M.; Lan, C. Adsorption of textile dyes on Pine cone from colored wastewater: Kinetic, equilibrium and thermodynamic studies. Desalination, v. 268, p. 117-125, 2011. https://doi.org/10.1016/j.desal.2010.10.007 
Molavi, H.; Hakimian, A.; Shojaei, A.; Raeiszadeh, M. Selective dye adsorption by highly water stable metal-organic framework: Long term stability analysis in aqueous media. Applied Surface Science, v. 445, p. 424-436, 2018. https://doi.org/10.1016/ j.apsusc.2018.03.189

Nascimento, A. C. C.; Cruz Filho, I. J.; Lima, V. F.; Nascimento Junior, A. J.; Marques, O. M.; Gondim, M. V. S. Biossorção do corante índigo carmim por Pennisetum purpureum Schumach. 1827 (Poales: Poaceae) (Capim elefante). Journal of Environmental Analysis and Progress, v. 2, p. 44-49, 2017. https://doi.org/10.24221/jeap.2.1.2017.1033.44-49

Nascimento, G. E.; Campos, N. F.; Silva, J. J.; Barbosa, C. M. B. D. M.; Duarte, M. M. M. B. Adsorption of anionic dyes from an aqueous solution by banana peel and green coconut mesocarp. Desalination and Water Treatment, v. 57, no. 30, p. 14093-14108, 2016. https://doi.org/10.1080/19443994.2015.1063012

Nascimento, G. E.; Duarte, M. M. M. B.; Campos, N. F.; Rocha, O. R. S. D.; Silva, V. L. D. Adsorption of azo dyes using peanut hull and orange peel: A comparative study. Environmental Technology, v. 35, p. 1436-1453, 2014. https://doi.org/10.1080/ 09593330.2013.870234

Nazir, R.; Khan, M.; Ur Rehman, R.; Shujah, S.; Khan, M.; Ullah, M.; Zada, A.; Mahmood, N.; Ahmad, I. Adsorption of selected azo dyes from an aqueous solution by activated carbon derived from Monotheca buxifolia waste seeds. Soil \& Water Research, v. 15, p. 166-172, 2020. https://doi.org/10.17221/59/2019-SWR

Nugroho, F. L. A comparative study on the removal of Remazol Golden Yellow 6 dye by mixed culture of dead fungal biomass and activated carbon. Jurnal Purifikasi, v. 9, no. 1, p. 1-8, 2008. https://doi.org/10.12962/j25983806.v9.i1.135

Panigrahi, T.; Santhoskumar, A. U. Adsorption process for reducing heavy metals in textile industrial effluent with low cost adsorbents. Progress in Chemical and Biochemical Research, v. 3, p. 135-139, 2020. https://doi.org/10.33945/SAMI/PCBR.2020.2.7

Saratale, R. G.; Gandhi, S. S.; Purankar, M. V.; Kurade, M. B.; Govindwar, S. P.; Oh, S. E.; Saratale, G. D. Decolorization and detoxification of sulfonated azo dye C. I. Remazol Red and textile effluent by isolated Lysinibacillus sp. RGS. Journal of Bioscience and Bioengineering, v. 115, p. 658-667, 2013. https://doi.org/10.1016/j.jbiosc.2012.12.009

Silva, P. C.; Oliveira Neto, G. C.; Correia, J. M. F.; Tucci, H. N. P. Evaluation of economic, environmental and operational performance of the adoption of cleaner production: Survey in large textile industries. Journal of Cleaner Production, v. 278, 2021. https://doi.org/10.1016/j.jclepro.2020.123855

Song, S.; Liu, Z.; Zhang, J.; Jiao, C.; Ding, L.; Yang, S. Synthesis and adsorption properties of novel bacterial cellulose/graphene oxide/attapulgite materials for $\mathrm{Cu}$ and $\mathrm{Pb}$ ions in aqueous solutions. Materials, v. 13, 2020. https://doi.org/10.3390/ma13173703

Srivastava, A.; Shukla, S.; Jangid, N. K.; Srivastava, M.; Vishwakarma, R. World of the dye. In: Wani K. A.; Jangid N. K.; Bhat A. R. Impact of textile dyes on public health and the environment. Hershey, PA: IGI Global, 2020. p. 1-19. https://doi.org/10.4018/978-17998-0311-9

Sukarta, I. N. Utilization of nata de pina as adsorbent for adsorption of Remazol Black B textile dyes. International Journal of Innovative Research and Advanced Studies, v. 2, p. 140-143, 2020. 
Tunç, Ö.; Tanaci, H.; Aksu, Z. Potential use of cotton plant wastes for the removal of Remazol Black B reactive dye. Journal of Hazardous Materials, v. 163, p. 187-198, 2009. https://doi.org/10.1016/j.jhazmat.2008.06.078

Ucar, D. Adsorption of Remazol Black Rl and Reactive Yellow 145 from aqueous solutions by pine needles. Iranian Journal of Science and Technology. Transactions of Civil Engineering, v. 38, p. 147, 2014.

Zanon, V. B. Estudo da adsorção do corante Reativo Preto 5 sobre carvão ativado: caracterização do adsorvente e determinação de parâmetros cinéticos e termodinâmicos. Blumenau: Universidade Regional de Blumenau, 2006. (Dissertação de mestrado).

Ziapour, A.; Sefidrooh, M.; Moadeli, M. R. Adsorption of Remazol Black B dye from aqueous solution using bagasse. Progress in Color, Colorants and Coatings, v. 9, p. 99-108, 2016. https://doi.org/10.30509/pccc.2016.75881 